\title{
MICROESTADOS EUROPEOS EN LA PERSPECTIVA DE LA NEGOCIACIÓN DE UN ACUERDO DE ASOCIACIÓN CON LA UNIÓN EUROPEA
}

\author{
JUAN F. LÓPEZ AGUILAR \\ Catedrático de Derecho Constitucional \\ Universidad de Las Palmas de Gran Canaria \\ Presidente de la Comisión de Libertades, Justicia e Interior del Parlamento Europeo
}

TRC, núm. 46, 2020, pp. 241-270

ISSN $1139-5583$

\section{SUMARIO}

I. Introducción: derecho comparado europeo y constitucionalismo. II. Noticia histórico-constitucional de los microestados europeos. III. Breve valoración de sus singularidades ante la perspectiva de su asociación con la UE. IV. Reflexiones conclusivas.

\section{INTRODUCCIÓN: DERECHO COMPARADO EUROPEO Y CONSTITUCIONALISMO}

En el Derecho comparado europeo perviven algunas rarezas sobre las que escasamente hemos posado la vista incluso quienes frecuentamos el estudio de ordenamientos extranjeros con método comparado. Los llamados microestados europeos $^{1}$ — minúsculo territorio y escasa población, entre los que se encuentran el Principado de Andorra, República de San Marino y Principado de Mónacorevisten especial interés desde la comparación y la integración europea ${ }^{2}$.

1 Véase, como introducción a la categoría analítica de los llamados microestados en la comunidad internacional, así como a su problemática distintiva, Dommen, E. \& HeIN, P., States, Microstates E Islands, Croom Helm, London, 2005.

2 Los microestados comprendidos en el objeto de este estudio no son los únicos en Europa. El Principado de Liechtenstein, integrado en el Espacio Económico Europeo/EEE y la Ciudad del Vaticano/Santa Sede, escaparán a este estudio, cada uno de estos con sus estructuras constitucionales de imposible homologación, puesto que por el momento no han adoptado estrategias de Asociación con la UE. Cfr. en general, véase sobre los microestados enclavados en Europa y sus peculiaridades históricas y políticas, EcCARDT, T.M.: Secrets of the 
En la doctrina jurídica, llamamos Derecho comparado a una aproximación al conocimiento de diversos ordenamientos con caracteres y exigencias propias, tanto desde su objeto como desde su método. Desde el punto de vista de su objeto, aceptamos que el Derecho comparado no se practica yuxtaponiendo o sumando referencias normativas extranjeras. No consiste en colacionar una sucesión de disposiciones foráneas, históricas o actuales, aun cuando su presentación resulte amplia o exhaustiva. La comparación jurídica cobra sentido si - y solo si- se antepone previamente un criterio para el cual el repaso o la mirada a ordenamientos extranjeros tenga alguna utilidad desde un enfoque acordado con el destinatario (los «lectores») del análisis. El principal interés de un ejercicio de comparación residirá en su pertenencia a una cultura legal con raices comunes y rasgos compartibles en algún ámbito de integración regional que ofrezca motivos de reflexión o arroje enseñanzas prácticas. Desde el punto de vista del método, el Derecho comparado ha ido cobrando cuerpo en los estudios académicos en las últimas décadas. Con antecedentes en la Teoría general del Estado y en la Historia general del constitucionalismo, todas las familias científicas de nuestro entorno, y en todas las ramas de estudio (privadas y públicas, civiles, societarias, administrativas, laborales, financieras, penales, procesales), lo han practicado enriqueciendo su acervo y favoreciendo soluciones prácticas a sus problemas (conflictos y litigios ante tribunales de Justicia, en el Derecho de casos: "Case Law"). El método de la comparación manifiesta sus elementos comunes, validando la ampliación del espectro de ese examen. Pero también, al mismo tiempo que ilustran que su trasfondo compartido (en el caso europeo, su incardinación en la cultura del constitucionalismo democrático y social que, tras la Segunda Guerra Mundial, conocemos como «modelo social europeo»), resaltan las diferencias espigables entre ellos. A saber, las singularidades y/o especificidades que nos ayuden a explicar lo que de irrepetible tiene cada experiencia de arquitectura estatal $-\mathrm{y}$, de paso, Nation-building, cultura y/o sentimiento de vinculación o demos- a través de la concreta herramienta del Derecho ${ }^{3}$. Los mejores desarrollos del Derecho comparado en nuestro entorno exhiben, desde este enfoque en que el método hace al objeto, un fuerte compromiso europeo. De su reciente desarrollo en España ${ }^{4}$, el Derecho comparado que se practica en Europa arraiga en los principios que dan al concepto de constitucionalismo europeo que explican sus tratadistas en esta disciplina ${ }^{5}$.

seven smallest States in Europe,:Andorra, y Liechtenstein, Louxembourg, Malta, Monaco, San Marino and the Vatican City, Hippocrene Books, New York, 2005.

3 Sobre el objeto y método de la comparación jurídica, Vid., por todos, De Vergottini, G., Diritto Costituzionale Comparato, Cedam-Padova; Pizzorusso, A., Corso di Diritto Comparato, Giuffré, Il Mulino, 1984; Lopez Garrido, D., Massó Garrote, M., y Pegoraro, L., Nuevo Derecho Constitucional Comparado, Tirant-Lo Blanch, Valencia, 2004, 7. ${ }^{\mathrm{a}}$ ed.

4 Del que es ejemplo el habitual capítulo de estudios de Derecho extranjero de la Revista de Teoría y Realidad Constitucional de la UNED fundada por el Prof. Alzaga.

5 Cfr., por todos, Lopez Garrido, D., Masso Garrote, M. y Pegoraro, L.: Nuevo Derecho Constitucional Comparado, cit. 
Es innegable, sin embargo, que transportar categorías dogmáticas de la Constitución y el constitucionalismo ${ }^{6}$ al Derecho europeo suscita - desde los inicios de la integración supranacional — algunas perplejidades tan recurrentes como difícilmente reductibles. Siquiera sea porque el vocablo constitucionalismo no alude sólo a la teoría de la interpretación de cada Constitución nacional, sino a un proceso histórico orientado a fundar, estructurar y limitar el poder político en Derecho. Esta segunda acepción resulta mucho más productiva a la hora de explicar la construcción europea. El material de trabajo para esta discusión —en la que el juicio de algunos autores hay mucho de wishful thinking y de voluntarismo- lo prestan las diversas piezas de ese sistema de «Derecho primario» de la UE: los Tratados fundacionales (1951 y 1957), sus sucesivas reformas y la desembocadura del ciclo constitucional europeo que es el Tratado de Lisboa (TL, en vigor desde el 1 de diciembre de 2009). La decantación progresiva de una cierta conciencia constitucional europea descansa en las interacciones entre el proceso de «constitucionalización de Europa» y los sistemas constitucionales de los Estados miembros (EE.MM) de la UE. En especial, el diálogo entre sistema judicial europeo (TJUE y, desconcentradamente, por la cuestión prejudicial, los órganos judiciales de los EE.MM) y las jurisdicciones internas ${ }^{7}$. El examen de las nociones que actúan como condición de su operatividad $^{8}$ ha venido empedrado por el acquis communautaire y por los leading-cases y, rulings del TJUE, impulsor de la idea de «Europa» como «Communauté de Droit» ${ }^{9}$, lo que exige analizar las cesiones de soberanía desde los EE.MM en las sucesivas reformas institucionales de la $\mathrm{UE}^{10}$. Reacondicionando el equilibrio de poderes (esto es, el Balance of Power entre los EE.MM y las Instituciones europeas); y superando el debate sobre el (a mi juicio mal llamado) «déficit democrático» de los fines a alcanzar por medio de la integración a escala supranacional ${ }^{11}$. Lo que conduce a relativizar razonablemente la — genuina, aunque

6 Sobre estas categorías, baste refrescar, por todos, el clásico texto de LoEwenstein, K. (1965, 1 Ed): Teoría de la Constitución, Ariel, Barcelona. Una lectura actual en Von Bogdandy, A., Cruz Villalön, P. \& Huber, P.M.: El Derecho Constitucional en el Espacio Jurídico Europeo, Tirant-Lo Blanch, Valencia, 2013.

7 La perspectiva de los derechos y de su elaboración jurisprudencial mediante el denominado «diálogo entre Tribunales y entre jurisdicciones» en los círculos concéntricos de la integración europea, la explica lúcidamente LOPEZ GUERRA, L., «Derechos e integración europea», en UGARTEMENDiA, J.I., JÁUREGUI, G., Derecho Constitucional Europeo, Tirant-Lo Blanch, Valencia, pp. 17-40, 2011.

8 Cfr., por todos, el cualificado testimonio de un antiguo Presidente del TC español y luego Abogado General ante el TJUE, Cruz Villalon, P., La Constitución inédita. Estudios ante la constitucionalización de Europa, Trotta, Madrid, 2004.

9 Véase Lopez Castillo, A., La Constitución de Europa a debate. Estudios sobre el complejo constitucional de la Unión, Tirant, Valencia, 2004.

10 Una reflexión aguda, y crítica, sobre los problemas irresueltos del proceso político y la gobernanza europea puede encontrarse en Torreblanca, J.I., ¿Quién gobierna en Europa? Reconstruir la democracia. Recuperar la ciudadanía, Ed. Catarata, Madrid, 2014.

11 Una explicación didáctica del alcance y de los límites del TL, entre otros tratadistas en la doctrina constitucional española, puede encontrarse en TAjadura, J., El futuro de Europa. Luces y sombras del Tratado de Lisboa, Comares, Granada, 2010. 
limitada- potencia transformadora del instrumento jurídico-constitucional en Europa $^{12}$. Con todo, la virtualidad del TL reside no solamente en haber reducido (a menudo denostada) maraña legislativa de los Tratados anteriores, sino en robustecer el estatuto de la ciudadanía europea reforzando al mismo tiempo al Parlamento Europeo (en adelante PE) como legislador ${ }^{13}$. Y en proclamar la Carta de Derechos Fundamentales de la UE con el «mismo valor jurídico» que los Tratados (art. 6.2 TUE) ${ }^{14}$. Ciertamente, desde entonces, la idea constitucional de la UE tiene más fuerza que nunca: para corroborarlo, baste pensar en que no existe ninguna organización de Derecho Internacional que cuente con un Parlamento multinacional directamente electivo; ni que proteja a sus ciudadanos con una Carta de Derechos supranacional y vinculante ${ }^{15}$, y un art. 2 TUE, que actualiza sus principios definitorios y valores comunes ${ }^{16}$. Pero sobre todos puntos nos hemos ocupado ya, de manera más extensa en otros escritos y publicaciones ${ }^{17}$.

Ahora, una vez enfocada la perspectiva comparada al objeto de estas páginas, habrá que posar la vista sobre lo que de común comparten y, contrastadamente, lo que de singular tienen tres concretos microestados enclavados en Europa ${ }^{18}$. De entrada, parece evidente que cada una de estas entidades estatales es en sí depositaria de una historia distintiva (reivindicada por ellos como «historia secular», «centenaria» o «milenaria»), singularísima en sus vicisitudes. Pero cada una de ellas es también el resultado o la desembocadura de un cúmulo de circunstancias que, llamativamente, explican su supervivencia y mantenimiento hasta hoy, en un contexto marcado por la vis atractiva de la integración regional y/o supranacional europea, y por la inexorable pauta de su globalización ${ }^{19}$. En su autoexplicación

12 Véase, sobre este estadio (que dio lugar posteriormente al desbloqueo del TL, Balaguer Callejon, F., Camara Villar, G., Una Constitución para Europa, Junta de Andalucía, Sevilla, 2005.

13 Un trabajo introductorio de este concepto en la literatura disponible en español, BARON CresPo, E., La constitucionalización del Poder Legislativo de la UE, Aranzadi, Madrid, 2006.

14 Sobre la dimensión operativa y efectos de la CDFUE —incorporada, «con el mismo valor jurídico», al ensamblaje del TL y con vigencia efectiva desde la misma fecha-, puede consultarse, entre otros, BALAGuer Callejon, F.: Estudios sobre el Tratado de Lisboa, Ed. Comares, Granada, 2009.

15 Cfr. la visión panorámica de López Castillo, A., La Carta de Derechos Fundamentales de la UE. Diez años de Jurisprudencia, Tirant-Lo Blanch, Valencia, 2019. Complementariamente, López CASTiLlo, A., LópeZ Guerra, L., «La Adhesión de la UE al Convenio Europeo de Derechos Humanos», en López Guerra, L. (Coord.): Constitución y Desarrollo. Homenaje al Profesor Jorge de Esteban, Tirant-Lo Blanch, Valencia, 2013.

16 Para un desarrollo en extenso del alcance dogmático y práctico de los «valores comunes» del art. 2 TUE y su conexión con el dispositivo sancionador contemplado en el art.7 TUE para el supuesto de «riesgo claro» de su «violación grave» o sistemática por parte de un E.M de la UE, vid. López Aguilar, J.F., El Parlamento Europeo: una experiencia única, Wolters-Kluwer, Madrid, 2020.

17 Véase su tratamiento en López Aguilar, J.F., Europa, Parlamento, Derechos. Paisaje tras la Gran Recesión, Tirant Lo Blanch, Madrid, 2017.

18 Cfr, más extensamente, KLIEGER, P.C., The Microstates of Europe: Design nations in a post-modern World, Lanham Lexington Books, 2014.

19 Sobre los escenarios de integración regional de los microestados, cfr. ANDriamandara, S., SCHIFF, M.W., Regional Groupings among Microstates, IMF, Washington D.C. Acerca de la correlación entre el tamaño o escala de los microestados y su configuración política e institucional, véase también VeenendaAl, W., Politics and Democracy in Microstates, Routledge, London, 1998. 
(revestida con tintes de autolegitimación y autorreivindicación), estos tres microestados europeos - Principado de Andorra, Principado de Mónaco, República de San Marino - exhiben una historia político-constitucional única, diferente en cada caso, de cuyos caracteres, no obstante, muy rara vez se ocupa el Derecho comparado europeo; ni siquiera en las comunidades académicas de los Estados fronterizos de su vecindad inmediata. Lo que resulta notable, teniendo en cuenta que han conseguido resistir, entrando en el siglo XxI, con una carga de experiencias tan irrepetible como sorprendente. Su peripecia es contigua a las de sus países vecinos (todos ellos actualmente estados miembros de la UE: España Francia e Italia). No obstante su proximidad, se han mostrado capaces de sostener estructuras arcaizantes, heredadas de pretéritos remotos, resilientes en su aproximación a las categorías del constitucionalismo europeo con el que interactúan ${ }^{20}$. En consecuencia, no es extraño que sus formas de gobierno y arquitecturas institucionales sean, sí, peculiares, cuyas piezas dan cuenta de sus itinerarios. Pero tampoco que esa resiliencia requiera de alguna explicación, máxime entre los estudiosos de los ordenamientos fronterizos con los suyos (es el caso de España, en la compañía de Francia, en su frontera con el Principado de Andorra).

Procedamos, así pues, a una somera noticia de los trayectos históricos de los tres microestados. Partiendo de las reconocibles divergencias entre ellos, y de las singularidades de cada uno de sus ordenamientos, su tratamiento conjunto responde aquí a consideraciones que pueden condensarse en dos. Por un primer lado, estos tres microestados han acordado dar cauce a una negociación para la conclusión de un futurible Acuerdo de Asociación con la UE (de naturaleza conjunta, sobre principios comunes, pero que deberá ser suscrito individualizadamente, por cada una de sus partes, con firma y ratificación tripartita entre la UE y sus contrapartes). Pero también, por otro lado, que tanto el Principado de Liechtenstein como la Santa Sede/Ciudad del Vaticano (que son los otros dos microestados incrustados en Europa, el primero de ellos un «paraíso fiscal» fronterizo con Austria pero aún más próximo a Suiza, adscrito al EEE y a Schengen, aunque no comparte el euro), exhiben estatutos propios, muy caracterizados por una mayor concentración de poder monocrático en su Jefatura de Estado (Gran Duque en Liechtenstein; el Papa en el Vaticano), y oponen consiguientemente una mayor resistencia a la comparación con el constitucionalismo democrático y social que sustenta los valores fundacionales de la $\mathrm{UE}^{21}$. Que son, por cierto, consagrados en el art. 2 TUE, y que el art. 6.3 del TUE refiere como «tradiciones constitucionales comunes», fuentes del Derecho de la UE en cuanto «principios generales». Repasemos seguidamente los trazos y características de estos tres microestados, cada uno único en su género.

20 Para un repaso comparado del alcance paneuropeo de estas categorías, cfr. SiEDENTop, L., Democracy in Europe, Columbia Univ. Press, N.Y, 2002.

21 Me remito aquí a mi libro Europa, Parlamento, Derechos, op. cit. 


\section{NOTICIA HISTÓRICO-CONSTITUCIONAL DE LOS MICROESTADOS EUROPEOS}

\section{Principado de Andorra}

Empecemos por Andorra, el más próximo a España. El principado de Andorra se enclava territorialmente en el Pirineo fronterizo entre el Reino de España (comarcas de Cerdaña, Alto Urgel y Pallars-Sobirá) y la República francesa (Departamentos de Ariége y Pirineos Orientales/Occitania). Sus orígenes históricos se remontan, como es obvio, a una remota antigüedad, con episodios señalados en una franja temporal de la extensa Edad Media ${ }^{22}$. Su historia describe al Principado de Andorra como un pequeño enclave rural que, durante siglos, permaneció aislado, diríase ensimismado, en su altitud enclavada en la frontera natural pirenaica, hasta que, a partir de la segunda mitad del pasado siglo Xx, con la prosperidad de la reconstrucción europea acentuada en los 60, desarrolló una industria turística y servicios financieros que le acarrearon una imagen de «paraíso fiscal» que se esforzado en corregir en su estrategia de aproximación a los estándares europeos. A partir de 2010 se adoptaron las reformas legales requeridas por la OCDE y el Consejo de Europa para poner fin a su notoria reputación de paraíso fiscal y asegurar la obligada transparencia fiscal y cooperación judicial en las investigaciones penales contra la corrupción, la ocultación de capitales y el blanqueo de dinero procedente de negocios ilícitos. En la actualidad, el Principat d'Andorra (en el que el catalán es la lengua oficial: de hecho, el único Estado soberano que oficializa esta lengua, aunque por la vecindad sean frecuentes el francés y el castellano) se constituye como un Estado social y democrático de Derecho con forma de gobierno parlamentaria. Miembro del Consejo de Europa, su Constitución vigente data de 1993.

En un repaso sumario, la historiografía andorrana exhibe orgullosamente las referencias de Polibio a los pobladores andosinos con que tropezó Aníbal al frente de su enorme ejército al cruzar los Pirineos. Los valles andorranos fueron incorporados al Condado de Urgel a mediados del s. IX. A partir del s. XIII, se afirmó su dominio feudal por los Condes de Foix, cuyo poder territorialmente se extendía desde el sur de Francia, a través del Reino de Navarra. De acuerdo con sus fuentes, fue Carlomagno (en los prolegómenos del Sacro Imperio Romano) quien primeramente reconoció entidad a este condado, pero fue a fines del s.XIII cuando se estableció la primera práctica de coprincipado entre el Conde de Foix y el obispo de Urgel. La fórmula embrionaria del «Consejo de la Tierra» (siete parroquias del principado) fue establecida en 1419, respetada por Fernando II de Aragón

22 Vid. sobre el específico caso del Principado de Andorra, Mallart I Casamajor, L., Microstats: un camí per al seu coneximent. Mocrostates: a path to its identification, Govern d'Andorra. Conselleria d'Educació i Cultura, Andorra La Vella, 1988. El texto es, no obstante su utilidad, anterior a la aprobación de la Constitución del Principado de Andorra de 1993. 
en 1512 (Fernando, viudo de Isabel I de Castilla, y luego casado con Germana de Foix), y ratificada por su nieto Carlos I en el momento de acceder al trono de España (1516) antes de ser coronado como Emperador Carlos V en Bolonia (1530). Arranca a partir de ahí una secuencia en que todos los monarcas (salvo, brevemente, Luis XIII) respetaron la «soberanía» e independencia de Andorra, que obtuvo el respaldo explícito de Inglaterra en el tablero de la reorganización de Europa post-napoleónica que definió el Congreso de Viena (1815). Es a partir de ese momento que se consolidada en la escena político-constitucional de Europa la solución bicéfala de su Jefatura de Estado compartida entre el obispo de Urgel y el jefe de Estado o Presidente de la República Francesa. En cuanto a los capítulos de su configuración político-administrativa, la llamada «Nova Reforma» (1866) inicia, a fines del s. XIX, el proceso de modernización de las estructuras feudales hasta entonces imperantes. Las incipientes modificaciones civiles introducidas entonces incluyeron el derecho de voto (masculino) para los cabezas de familia; la limitación e incompatibilidad de mandato de Consejero y Cónsul; el número de Consejeros en cada una de las parroquias; y la creación de un Comisionado del Pueblo para la fiscalización externa de las cuentas públicas. Sólo avanzado el s. XX (1970) se generalizó en Andorra el sufragio universal, extendiéndolo por fin a las mujeres, tras una sucesión de disrupciones ligadas a las contiendas libradas en suelo europeo. La fórmula de la democracia representativa se consolidó tan sólo a fines del pasado s.XX (1982, primer Gobierno representativo derivado de elecciones y responsable ante el Consejo, con afirmación del principio de responsabilidad política), estadio desde el que se abre paso el proceso de elaboración de la Constitución de 14 de marzo de 1993, aprobada en referéndum. A partir de esta Constitución escrita, Andorra se constituye como Principado parlamentario, soberano, representado con acreditación diplomática ante NN.UU. y ante los Estados y organizaciones supranacionales de su entorno europeo. Transitando, desde su antigua estructura económica como Estado agrícola y ganadero, hacia su caracterización actual como destino turístico y prestador de servicios, Andorra no ha aspirado nunca a ser un nuevo Estado miembro de pleno Derecho de la UE, aunque ha establecido con esta (desde los años 90 del pasado s.XX) relaciones comerciales crecientemente articuladas.

En el transcurso de este tiempo, su sector financiero ha debido acusar el impacto de la estrategia proeuropea contra su tradicional principio de secreto bancario. Presionada por la UE (y en modo particular por sus EE.MM fronterizos), el Gobierno andorrano ha ejecutado una estrategia de reformas para dejar de ser considerado «paraíso fiscal» tanto por la OCDE como por la propia UE, firmando una amplia panoplia de Tratados de Intercambio de Información Fiscal que arranca en 2010. Carente de moneda propia, el Principado de Andorra mantuvo de facto desde siempre las denominaciones monetarias de sus países vecinos (Francia, España) hasta su definitiva introducción del euro (2002). Para adaptar su economía a la nueva moneda común europea, Andorra firmó con el BCE en 2011 su propio Acuerdo Monetario (ratificado en 2012), creando asimismo el 
marco que permite a la Autoridad Financiera andorrana y las autoridades bancarias andorranas la emisión de moneda en euros a partir de $2014^{23}$. En cuanto a su capacidad de Defensa, el Principado de Andorra carece de ejército y, consiguientemente, de una estrategia defensiva en ausencia de Fuerzas Armadas (cuenta con un reducido cuerpo de policía a partir de 1931, así como de un somatén para el caso de emergencias o desastres). En consecuencia, se apoya en la posibilidad de movilizar la ayuda de las autoridades españolas o francesas en caso de necesidad grave, conforme a lo establecido en el Tratado Trilateral (Andorra, España, Francia) de Amistad, Vecindad y Cooperación ${ }^{24}$.

De los tres microestados agrupados en la estrategia del Acuerdo de Asociación con la UE, que son objeto de estas páginas, el Principado de Andorra resulta ser, curiosamente, el más poblado. Su demografía da cuenta de una creciente apertura a influencias foráneas $\mathrm{y}$, consiguientemente, también de una pauta ascendente de pluralismo social, político e incluso religioso. Su sistema de partidos refleja esa fragmentación: Demòcrates per Andorra, Partit Socialdemòcrata, Partit Liberal d'Andorra y Tercera Via compiten por representación en su Consejo General desde las circunscripciones de las siete parroquias, en las que el valor de voto experimenta un marcado sesgo territorial dada la desigual distribución de la población con derecho a voto en cada una de ellas. Desde el punto de vista sociológico, el microcosmos andorrano fue tradicionalmente homogéneo, mostrando rasgos de endogamia explicables por su orografía y aislamiento. Con el tiempo, ha acusado el impacto de su exposición a factores exógenos, en modo que en la actualidad es perceptible una diversidad cultural y religiosa superior al de ningún estadio anterior de su historia, sin perjuicio de lo cual el censo de población residente $-\mathrm{y}$, consiguientemente, de las condiciones jurídicas para la adquisición de la nacionalidad y ciudadanía andorrana - continúan siendo objeto de una celosa estrategia de control que sigue siendo prioritaria para los sucesivos gobiernos del Principado.

La consolidación de la práctica parlamentaria se conjuga en Andorra con una Jefatura de Estado bicéfala: es la tradicional fórmula del coprincipado cuyos titulares son copríncipes; respectivamente: el Presidente de la República francesa (fórmula que data de la monarquía francesa y sobrevivió a las Revoluciones, al Imperio napoleónico, y a todas y cada una de las experiencias constitucionales de República francesa) y el titular de la prelatura de la Seu de Urgell (obispado cuya sede se sitúa en la provincia de Lleida, Cataluña, España). Es fácilmente entendible, tras esta configuración histórica del Principado de Andorra, la referida ausencia de Ejército regular: ejercen la fuerza pública un cuerpo de policía y extinción

23 Vid. Espasa Araña, J., Terceño Gomez, A., El desarrollo de la contabilidad en los microestados europeos durante el período 1993-2003: el caso especial de Andorra, Univ. Rovira i Virgili, Tarragona, 2007.

24 Sobre la incardinación de Andorra en su contexto europeo y en la comunidad internacional, puede consultarse el reciente estudio de BATLle, A., «Andorra y el concierto internacional (y europeo)», Anuario Internacional CIDOB 2020, 2020, pp. 257-268. 
de incendios (cuyos orígenes datan de 1931) y un consuetudinario dispositivo de somatén. Es esta una institución históricamente arraigada en la tradición catalana, desde el tránsito de la modernidad a la era contemporánea, basada en la organización de unas reducidas partidas rurales de voluntarios para la defensa y la protección civil ante emergencias o desastres naturales. A partir de la entrada en vigor de su Constitución de 1993, Andorra asegura su propia representación diplomática mediante una red de embajadas, proporcionada a su tamaño y sus capacidades, que incluye sus Estados fronterizos y las principales organizaciones internacionales y supranacionales de su encuadre (NNUU, OCDE, Consejo de Europa, UE).

En cuanto a su consolidación constitucional, Andorra aprobó su Constitución en 1993, en lo que sin duda fue un paso adelante celebrado en los países de su entorno. Su Constitución consagra un Estado constitucional de Derecho y una forma de gobierno parlamentaria para el Principado basada en la consagración del derecho de sufragio y de participación política como derecho fundamental de la ciudadanía andorrana. Por cierto: La Constitución andorrana consagra, así, por vez primera con rango constitucional, el sufragio universal femenino, una conquista democrática y de la igualdad en derechos que, tras muchas vicisitudes y no poco debate social, había sido establecido previamente por ley en una fecha tan tardía como 1973.

Su parlamentarismo se articula en torno a la elección por sufragio universal (partiendo de sus siete parroquias como circunscripciones) de su Consell General (Parlamento andorrano), órgano que inviste al Gobierno (habitualmente de coalición), a cuyo frente se sitúa la Jefatura del Gobierno (Cap de Govern). El Consell General (históricamente denominado Consell dels Valls d'Andorra) se compone, a su vez, de veintiocho miembros (con representación actual de hasta cinco partidos, elegidos en siete parroquias), con sede en la capital, Andorra la Vella. En cuanto a su Poder Judicial (en cuya regulación resulta constitucionalmente posible el reclutamiento temporal de jueces y fiscales de nacionalidad no andorrana, por regla general españoles o franceses), se estructura éste en un Juzgado de primera instancia civil y administrativo (Bailía) y un Tribunal de Cortes de primera instancia penal. Por su parte, el Tribunal Superior de Justicia de Andorra (que cuenta con un presidente y con ocho consejeros) ejerce jurisdicción de apelación. El Tribunal Constitucional (creado ex Constitutione, con su Presidente y tres miembros) es el máximo intérprete de la Constitución y garante de su supremacía. Además, el ordenamiento andorrano cuenta con un Consejo Superior de la Justicia (órgano de gobierno y administración interna del Poder Judicial, garante de su independencia y del régimen estatutario de la judicatura). En lo que respecta su pequeña organización administrativa, el Principado de Andorra se estructura en siete comunes (entes locales dotados de órganos de representación y gobierno de sus respectivas parroquias (demarcaciones territoriales), elegidos cada cuatro años por sufragio universal y directo de la ciudadanía andorrana. Se trata de corporaciones dotadas de personalidad jurídica, potestades normativas y autonomía local, cuya composición oscila de 
ocho a catorce consejeros entre los que elegirán sus respectivos Cónsules (llamados mayor y menor). Las corporaciones locales prueban y ejecutan sus presupuestos propios y ostentan iniciativa legislativa local ante el Consell General. Y en materia de derechos (habitual parte dogmática del constitucionalismo escrito), la Constitución andorrana de 1993 incluye un título amplio de libertades fundamentes y garantías judiciales, supuesto sobre el que Andorra se incorpora a la comunidad internacional de los derechos bumanos (Consejo de Europa, CEDH, NNUU y DUDH). Cuenta además con una institución permanente, el Raonador del Ciutadá (Ombudsman), para velar especialmente por las cláusulas antidiscriminación.

\section{Principado de Mónaco}

Nuestro segundo microestado, el Principado de Mónaco (Principauté de Monaco) es un Estado soberano. Después de la Santa sede/Ciudad del Vaticano, es el Estado de más reducida dimensión territorial de Europa, y en realidad del todo el mundo, pero resulta al mismo tiempo el más densamente poblado de toda Europa. Su forma de gobierno es la monarquía constitucional (sí, constitucional, esto es, no parlamentaria, puesto que aun hoy mantiene una reserva de poderes para el jefe del Estado, el príncipe de Mónaco). Su actual organización político-administrativa descansa sobre la base de su Constitución de 1962, y cuenta con una organización territorial que cuenta con diez distritos.

El primer dato singular que sobresale al observar las magnitudes descriptivas de este precipitado histórico como Estado soberano en Europa y en el mundo, es la desproporción entre la población que ostenta ciudadanía monegasca con plenitud de derechos civiles y políticos, y la que reside en la minúscula franja de costa en que se enclava la Roca de Mónaco y la villa alrededor, con un excepcionalmente alto nivel de renta y bienestar ${ }^{25}$. En efecto, del total de habitantes apenas cerca del veinte por ciento del total ostentan ciudadanía monegasca. El resto son ciudadanos europeos imantados por las condiciones fiscales convenientes a sus rentas.

La lengua oficial es el francés, aunque la población monegasca se precia de practicar los dialectos monegasco y occitano del francés además del italiano. Su historia remota se remonta a la presencia del comercio entre ligures y fenicios. Un puerto fundado por esto últimos, Melkart, al que los griegos dieron el nombre de Monikos se encuentra seguramente en la etimología de su denominación, que transitó al nombre romano de Portos Herculis Monaeci (s.I). Los sucesivos estadios de dominación visigoda, franca, lombarda, carolingia y del Sacro Imperio Romano (instituido por los francos) describen un itinerario de mestizaje estimulado por el poder de atracción de su salida al mar. Su proximidad con Italia explica que se mantuviese ligado a la peripecia itálica (Liguria, fenicia, dominación visigoda y

25 Cfr. el informe de IMSEE: Monaco en chiffres, Ministère d'État, Monaco, 2017. 
lombarda hasta su incorporación al imperio carolingio y luego al Sacro Imperio Romano Germánico) a todo lo largo de su historia previa a la Era Moderna que arranca en el Renacimiento. Por ello, la lengua dominante en Mónaco fue el italiano hasta 1860 (consecuencia de su dominación por la República de Génova desde 1297, y su posterior adquisición por la familia Grimaldi, fundadora de la dinastía hasta la fecha reinante), sorteando mil refriegas hasta la anexión francesa del Condado de Niza a fines del siglo XIX, en que germinó el francés como lengua prevalente. Según la interpretación comúnmente aceptada, los orígenes de la entidad política de Mónaco arrancan cuando en 1215 los genoveses construyen un castillo defensivo en la Roca de ese nombre como bastión de frontera. A partir de la figura de Francesco Grimaldi (1297), unida a de la de su primo Raniero I, aliado de Felipe el Hermoso Rey de Francia, queda entablada una dinámica de competición política y tensión cronificada entre la monarquía francesa y los condottieri genoveses en esa franja estratégica frente al mediterráneo, cuya desembocadura en favor de los Grimaldi cimienta una dinastía que, sobreviviendo a los cambios y revoluciones en su entorno, se ha prolongado hasta hoy ${ }^{26}$. Los arcos históricos del Renacimiento y de la Era Moderna hasta la Contemporánea contemplan la articulación y despliegue progresivo de una extensa serie de Tratados internacionales diseñados para proteger su incipiente soberanía en el movedizo mapa de Europa a su alrededor: así, por ejemplo, con Francia (1409, 1641 y 1861); con España (1512, reinando Juana en Castilla y Fernando en Aragón): o con el reino de Cerdeña (Congreso de Viena, 1815). La sucesión de ciclos revolucionarios en Francia (1789, 1830 y 1848) determinó largo tiempo, con su inevitable impacto, la correspondiente secuencia de las vicisitudes políticas del Principado. Así, hasta 1847 el Principado contó con tres comunas - Mónaco, Roquebrune y Mentón-, aunque, durante los sucesos revolucionarios de 1848, estas dos últimas comunas votaron su anexión a Francia, posteriormente ratificada en el Tratado franco-monegasco de 1861. En 1865 siguió el Convenio bilateral de aduanas y fronteras. De forma inmediatamente sucesiva, bajo el reinado de Alberto II Grimaldi se inicia una nueva etapa de moderación del absolutismo (1869). En suma, sobreviviendo a los intensos ciclos revolucionarios franceses (y sus sucesivos epígonos con alcance en toda Europa, 1789/1794, Imperio napoleónico en 1804, 1815 y Congreso de Viena, 1830, 1848), Mónaco consiguió, asombrosamente, pervivir en todo momento como una «ciudad libre» hasta su la aprobación de su primera Constitución escrita de 1911 (reformada en 1917 y 1930) bajo el reinado de Carlos III, que fue a su vez el preludio y el contexto jurídico de la entronización de Rainiero II (1949) tras la II Guerra Mundial (con sucesivas ocupaciones italiana y alemana, y posterior liberación por las fuerzas de EEUU).

26 Un recorrido panorámico en Fouilleron, T., Histoire de Monaco, Direction d'Education et Sports, Monaco, 2016. 
A todo lo largo de esta secuencia histórica que incluye la entrada en vigor de la Constitución monegasca de 1911, el Príncipe como Jefe de Estado disponía de los poderes ilimitados propios de una monarquía absoluta. En esos primeros años del siglo, bajo el reinado de Carlos III de Mónaco, se promovieron obras públicas y edificios monumentales. En esa etapa se inscribe el Tratado defensivo con Francia (incorporado luego a los protocolos del Tratado de Versalles de 1919, que delineó el mapa de Europa tras el fin de la Gran Guerra). Ocupado posteriormente por los nazis en septiembre de 1943, el territorio monegasco fue liberado por tropas de EEUU en el verano de 1944 (operación Dragoon), con el restablecimiento de la relación diplomática privilegiada del Principado de Mónaco con la República francesa (restablecida entonces como IV República por la Constitucion francesa de 1946).

Con la adopción de la Constitución del Principado de Mónaco de 1962, se introdujo por primera vez un Título dedicado a consagrar y garantizar judicialmente los derechos fundamentales de la ciudadanía monegasca, incluido el derecho fundamental de participación política a través del sufragio universal. Así, pues, curiosamente, el Principado de Mónaco resulta ser el primero de los tres microestados objeto de este comentario en haber establecido el sufragio universal femenino, a inicios de los años 60 del pasado siglo xx. Un rasgo definitorio de la Constitución de 1962 es la caracterización de la forma de gobierno del Principado como monarquía constitucional. Lo que quiere decir que el Principado de Mónaco se reclama a las categorías que en la doctrina española asociamos a la historia del liberalismo doctrinario, en los que la soberanía reside tanto en el Rey (Príncipe, en este caso) como en la representación de la soberanía nacional. Un modelo en que el monarca desempeña amplios poderes arbitrales y de intervención decisiva en la formación de Gobierno y en la designación de un jefe del Ejecutivo (llamado «Ministro de Estado») de su elección y confianza, así como en la moderación de la actividad legiferante e incluso en la dirección de la política exterior, la acción exterior y la representación diplomática del Estado, así como en la orientación general de la actuación administrativa. Llamativamente, todavía hoy Mónaco contempla en su Constitución de 1962 la religión católica como «oficial del Estado». Pervive hasta hoy, sin embargo, una minoría judía que cuenta con una sinagoga en una normalizada tolerancia religiosa.

En cuanto a su peculiar estructura constitucional, el Poder Ejecutivo lo ejerce un Gobierno presidido por un Ministro de Estado (que debe ser ciudadano francés o ciudadano monegasco), designado por el Príncipe (habitualmente tras consulta con el Gobierno de la República francesa). Su Constitución de 1962 establece, en los términos característicos del constitucionalismo doctrinario propio del último tercio del s. XIX (no ciertamente del s.XX), que el poder legislativo es compartido entre el Príncipe (monarca) y una Asamblea unicameral/ Consejo Nacional de Mónaco, con veinticuatro miembros elegidos por sufragio universal entre los/as ciudadanos/as de nacionalidad monegasca, por un período de cinco años, con potestad legislativa y potestad de desarrollo reglamentario de los así denominados Decretos 
Reales $^{27}$. El Poder Judicial del Principado de Mónaco se articula simplemente en una Corte Suprema de Mónaco como alto tribunal de apelaciones y de garantía de los derechos reconocidos en la Constitución de 1962. Cuenta con 5 miembros principales y dos Jueces adjuntos nombrados por el Príncipe a propuesta del Consejo Nacional. Respecto a su gobierno local, las materias de competencia municipal son atribuidas al Concilio Comunal (15 miembros electivos, que eligen a su alcalde). La singularidad más remarcada del Derecho constitucional monegasco reside en la primacía política del Príncipe, actualmente Alberto II, heredero de la dinastía Grimaldi que viene ostentando el poder desde 1297. El Príncipe ostenta, en efecto, capacidades que exceden las habitualmente simbólicas y metarrepresentativas de la Corona en el Derecho comparado de las jefaturas de Estado de su entorno europeo. Su influencia, poder de decisión y arbitraje en el sistema impactan tanto por la resiliencia de su orientación doctrinaria como por situarse fuera del debate político (au dessus de la melê), la disputa partidaria y la crítica de los medios de comunicación de la ciudad-estado. Las relaciones exteriores del Principado de Mónaco encuadran progresivamente a este microestado en la comunidad internacional, superando poco a poco su tradicional acomodo en un perfil bajo aparejado a una relativa ausencia de visibilidad. El Principado de Mónaco es en la actualidad miembro de NNUU, desde 1993, y del Consejo de Europa desde 2004 (parte por tanto del CEDH y sujeto a la jurisdicción del TEDH). Mónaco es asimismo Estado miembro de la OMS y la UNESCO. Como puede comprenderse, también el Principado de Mónaco carece de ejército propio, manteniendo sin embargo una simbólica unidad de Guardacostas. Cuenta, sí, con una Policía propia y una Guardia Real (Compagnie des Carabiniers du Prince). Su defensa es asegurada por la República Francesa. En cuanto a su organización social, cuenta con una red de Colegios Profesionales y una Union des Syndicats. Y en su organización administrativa, Mónaco-Ville es la capital en que se encuadra La Roca, zona identificada con el área gubernamental y el Palacio. Contando con un único municipio, su organización se articula en los llamados «quartiers» (Fontvielle, Monegeti, Larvotto, La Rousse/San Roman, Sdan Miguel, La Colle, Les Revoires y Les Portiers).

De los tres microestados agrupados por la negociación del Acuerdo de Asociación con la UE, el Principado de Mónaco es el que, seguramente, ha conservado hasta hoy rasgos constitucionales de más intensos resabios arcaizantes. La preeminencia del Príncipe como jefe del Estado con amplios poderes de reserva e intervención política, ante el que responde el ministro de Estado como una suerte de vicario de su poder político administrativo sobre los asuntos ordinarios, se perfila como una rareza que, sin embargo, no ha impedido al Principado incorporarse al círculo concéntrico de integración europea que es el Consejo de Europa (con su adhesión al CEDH, participación en el TEDH y consiguiente sujeción a su jurisprudencia) y,

27 Sobre la resistencia de la monarquía monegasca a parlamentarizarse, y sobre los factores que explican la singular resiliencia del carácter doctrinario de su forma de Estado y de Gobierno, cfr. D’ONORIO, J.B., Monaco, Monarchie et Démocratie, PUAM, Aix en Provence, 2016. 
cuyas bases fundacionales se vinculan a la promoción del Estado de Derecho, el imperio de la Ley, la democracia representativa con gobiernos dimanantes de elecciones libres y periódicas, y los derechos fundamentales judicialmente protegidos por un Poder Judicial independiente ${ }^{28}$. Ahora bien, tampoco en una somera noticia histórico constitucional sobre las singularidades de este microestado europeo deberían ignorarse los más recientes esfuerzos del Principado de Mónaco por contrarrestar su notoria reputación de paraíso fiscal, factor este determinante en la orientación de sus relaciones estratégicas de futuro con la UE. En el año 2000 la Asamblea Nacional francesa debatió (Rapport Montebourg/Peillon) los problemas planteados por la fiscalidad monegasca a la lutte contre le blanchiment de capitaux en France. La OCDE publicaba (1998) un Informe asimismo crítico con la tradicional opacidad del Principado, identificado también como paraíso fiscal por el FMI en 2003. De ahí que, en el transcurso de las negociaciones para la adhesión de Mónaco al Consejo de Europa, esta organización forzó a Mónaco a incorporar reformas, escrutadas en sucesivas rondas de información pública $(2006,2007)^{29}$. Como consecuencia de esta estrategia, en 2009 Mónaco consiguió abandonar la llamada «lista negra» de la OCDE. Adicionalmente, el entablamiento formal de las negociaciones orientadas a la conclusión de un Acuerdo de. Asociación de la UE con los tres microestados europeos comprendidos en estas páginas, impuso una nueva pauta de reformas institucionales con el proclamado objetivo de que el Principado abandonase la llamada «lista gris» de la Comisión Europea. En este último supuesto, procede aclarar que se trata de uno de los instrumentos de análisis de las condiciones de cooperación financiera y de información fiscal en investigaciones penales que surgen de las conclusiones de la Comisión especial (Inquiry Committe) instituida por el PE en su Legislatura 2014/2919 a partir de los escándalos LuxLeaks, Panama Leaks/ Panama Papers, con el fin de reforzar el compromiso normativo de la UE y sus EE.MM contra las prácticas de evasión y fraude fiscal (dumping fiscal y agressive Tax Planning), y para establecer las bases de una lucha conjunta contra los paraísos fiscales, tanto dentro de la UE y sus EE.MM como en sus relaciones con los Estados terceros.

La reseña breve de sus singularidades económico-fiscales debe completarse advirtiendo que el Principado de Mónaco no regula ni establece ninguna imposición sobre la renta a sus habitantes.

\section{República de San Marino}

Nuestro tercer microestado, la así llamada Sereníssima Repúbblica di San Marino es en la actualidad, un Estado soberano. Se trata de una República parlamentaria

28 Un examen institucional en Grinda, G., La Principauté de Monaco. L'ètat, son statut international, ses institutions, Éditions A. Pedone, Paris, 2009.

29 Véase InAm, P., Exchange Rate of Microstates, IMF, Washington D.C, 2010. 
que se precia, cómo no, de ser «la más antigua del mundo», enteramente enclavada en el territorio de la República Italiana que la circunda (Regiones de Emilia-Romagna y Le Marche). Su lengua oficial es el italiano, y su jefatura de Estado -bicéfala como la del Principado de Andorra - viene constitucionalmente asegurada por la convivencia en el cargo de dos Capitani-Reggenti elegidos regularmente por el órgano legislativo elegido por sufragio universal —el Consejo Grande y General de San Marino- por períodos de seis meses, con lo que su renovación es tan intensa como continua ${ }^{30}$.

El minúsculo Estado de San Marino comparte con la Ciudad del Vaticano la característica geográfica de encontrarse circundado enteramente por Italia. Su historia es, por consiguiente, una storia italiana, en las que las turbulencias del Papado y los Estados pontificios (con sus querellas y disputas entre papas y antipapas coexistentes en el tiempo) y la sucesión de guerras entre güelfos y gibelinos se extienden desde la baja Edad Media hasta el Renacimiento. Su relato emerge entreverado de episodios legendarios, desde su fundación hasta su configuración (s.X) en comunidad monástica. La fecha oficial de la fundación de la plaza se remonta al año 301. El autogobierno de su Arengo (fórmula primigenia de su comuna en la roca inexpugnable situada en el Monte Titano) cualifican a San Marino como «la República más antigua del mundo», remontándose su fórmula de los Capitani Reggenti tan lejos como hasta el s. XIII en que el Papa Nicolás IV reconoció su independencia de los Estados pontificios y, consiguientemente, su plena soberanía (1291). Aunque su territorio se limitó a Titano hasta entrado el s.XIV, es a partir de su entrada junto a la Santa Sede en la alianza militar contra los Malatesta, entonces señores de Rimini, cuando el Papa Pio II amplió la jurisdicción originaria de San Marino a las ciudades vecinas de Fiorentino, Montegiardino y Serravalle, a las que se unió de inmediato la ciudad de Faetano. Sobre esa demarcación, el Arengo de San Marino entra en la modernidad procediendo a su codificación de normas constitucionales en 8 de octubre de 1600: tras esta codificación, el Papado ratificó su independencia respecto de los fronterizos Estados pontificios en 1631; Francia lo hizo en 1797 (por su Consulado emergente del período revolucionario); y el Congreso de Viena —que fijó históricamente el mapa de Europa después de la definitiva derrota del emperador francés Napoleón Bonaparte- certificó definitivamente su encuadre en el mosaico europeo en 1815. Los episodios revolucionarios del Risorgimento se sucedieron sin violar su estatus de soberanía, ratificada en el Tratado de 1862 de Relaciones Bilaterales con el entonces emergente Reino de Italia (Tratado luego revisado con el Fascismo de Mussolini en 1939, y finalmente actualizado con la República Italiana en 1971). Se entiende pues, fácilmente, que, tal y como sucede con el Principado de Mónaco y la República Francesa en todo lo relativo a la garantía de su defensa,

30 Para una aproximación, puede consultarse el estudio clásico de MiLler, W., «The Republic of San Marino», The American Historical Review, 6 (4), 1901, pp. 633-649. 
la soberanía de San Marino depende, esencialmente, de la garantía que le presta la República italiana. Por lo que, habiendo sido ocupada por la Webrmacht en 1943 (tras los sucesos que determinaron la caída de Mussolini por el Gran Consiglio Fascista, su confinamiento en Gran Sasso y su espectacular rescate por Otto Skorzeny), la República de San Marino hubo de esperar a la derrota definitiva de la Alemania de Hitler (mayo de 1945) y a la liberación definitiva de Italia y el establecimiento de la República Italiana (tras el referéndum que acabó con la monarquía en 1946, y su Constitución de 1948) para el restablecimiento pleno de su independencia y Gobierno.

En cuanto a su estructura constitucional, la soberanía y forma de Estado de la República de San Marino cristalizan en la actual compilación de Leyes Estatutarias de la República de San Marino (Leges Statutae Republicae Sancti Marini). Integran la Constitutio de 1600 (obra de Pier Matteo Belluzzi y Fabrizio Belluzzi como Capitani Reggenti) y su Declaración de Derechos de 1974 (ampliamente modificada y actualizada en 2002). Su codificación incorpora claras influencias del Corpus Iuris Civilis y de las convenciones y prácticas del Derecho consuetudinario que se remonta en la historia hasta el Derecho romano. Es por ello por lo que este ensamble de Leyes Estatutarias es a menudo narrado por la literatura disponible como de «más antigua data» de los actualmente vigentes en toda Europa - «iy en todo el mundo!», al decir de los sanmarinenses-, articulando en todo caso un vestigio inveterado cuyo estudio requiere técnicas casi paleográficas. La legitimación electiva de su modalidad de gobierno local se ha afirmado en la historia de manera progresiva desde la «Revolución» pacífica de 1906, en modo que, sobreviviendo a las catástrofes de las dos guerras mundiales, llega hasta nuestros días como un experimento único de constitucionalismo arcaico y, sin embargo, enmarcado en su inexorable coordenada italiana y europea. Conexa con su fronteriza Región italiana de la Emilia Romagna, la República de San Marino fue gobernada inicialmente $(1945 / 1957)$ por una coalición de izquierda liderada por los comunistas, luego sucedida por otra larga fórmula consociativa liderada por los democristianos con participación de los socialdemócratas (1957-1973), y con liderazgo comunista entre 1978 y 1993. Apoyándose en grandes consensos promovidos por gobiernos de amplia coalición, la República de San Marino ingresa en el Consejo de Europa en 1988 (por lo que es parte del CEDH, sujeto a la jurisdicción del TEDH), así como en NNUU (1992). Y adopta oficialmente el euro como moneda (2002), pese a no ser, como es obvio, EM de la UE ${ }^{31}$. Sus relaciones internacionales se mueven en el espectro de esos círculos principales de la articulación de su entorno europeo e internacional, contando con Embajada permanente ante Italia, ante la UE y ante NNUU.

Aunque tradicionalmente San Marino tuvo en el citado Arengo su órgano de gobierno (configurado inicialmente como Asamblea censitaria de los «cabezas de

31 Cfr. a este respecto ECCARDT, T.M., op. cit, 2005. 
familia»), es sin embargo en el tránsito desde la baja Edad Media a la Modernidad cuando la institución declina progresivamente los poderes de designación de sus Capitani Reggenti en un Consejo General. El órgano legislativo de la República de San Marino reside en la actualidad en el Consiglio Grande e Generale, electivo cada 5 años por sufragio universal de la ciudadanía de la Repbblica Serenissima. Nótese, a este respecto que ¡el sufragio femenino sólo fue introducido en 1973, haciéndose efectivo por vez primera en su historia en las elecciones de 1976! Compuesto por sesenta miembros por representación proporcional en nueve circunscripciones (los llamados Castelli, cada una de ellas con su respectivo Consejo y Capitán electo cada 5 años), el Consiglio — Parlamento de San Marino- procede a la elección (en una convención de riguroso equilibrio interpartidario, entre los principales partidos, consolidada por el uso) a sus dos Capitani-Reggenti. A partir de su elección, ambos Capitanes Regentes comparten por sólo 6 meses (con renovación incesante de las personas que rotan) su función siamesa de Jefatura del Estado estrictamente bicéfala, y cuya firma en concurso es requerida para la promulgación y entrada en vigor de toda la legislación y de los presupuestos aprobados por el Consiglio Grande e Generale. Este Consiglio o Parlamento se estructura a su vez en hasta cinco Comisiones de Asesoramiento compuestas cada una de ellas por 15 miembros, con la función de preparar, diseñar y debatir las leyes sobre las que delibera y vota el órgano en su composición plenaria. El Consiglio desempeña también funciones de ratificación de acuerdos internacionales y de elección de los restantes órganos que vertebran la estructura constitucional del Estado: il Congresso di Stato, il Consiglio dei Dodici, il Comitato d'Assessori... Pero asegura además la renovación regular (por acuerdo y transacción entre los partidos más representativos) de las dos personas que desempeñarán colegiada y mancomunadamente la Jefatura del Estado por períodos de 6 meses constitucionalmente regularizados: su toma de posesión tiene lugar puntualmente cada 1 de abril y cada 1 de octubre, en ceremonia solemne, altamente protocolizada, con la manifiesta intención de que el Consiglio remede en su ritualidad al Senado de la antigua República romana, mientras los Capitani asemejan a los Consules históricos. A su vez, el Consiglio elige al Congresso di Stato, órgano ejecutivo de gobierno de la República. Se trata de un Gabinete que cuenta con diez Secretarías (ministerios) presididas por un Secretario de Estado para Asuntos Exteriores y Políticos. La misma legitimación recibe el Consiglio dei Dodici (órgano judicial de última instancia y apelación) al que se adjuntam los inspectores judiciales del gobierno judicial en cuestiones financieras y de medios materiales. Complementan su minúsculo Poder Judicial sanmarinés los Jueces de primera instancia (habitualmente italianos) y los Jueces de Paz competentes en asuntos civiles de menor cuantía. Tal como se colige, el sistema judicial de San Marino descansa, por razones comprensibles, en la designación de jueces y magistrados foráneos (habitualmente italianos, a los que difícilmente cabe conceptualizar o percibir como «extranjeros» en la República Serenísima): sólo sobre los Jueces de Paz pesa la obligación de la ciudadanía sanmarinense de origen. Su organización administrativa consta en la actualidad de 
nueve municipios o castelli (a los anteriormente mentados se han sumado los de posteriores reformas de su administración local).

El sistema político de la República de San Marino es intensamente multipartidista, aun en el microcosmos de una población muy limitada. Los principales partidos de su arco parlamentario son el Democristiano, el Partido Socialdemócrata, Alianza Popular, Izquierda Unida de San Marino (antiguo Partido Comunista) y el Nuevo Partido Socialista de San Marino. En cuanto a su financiación, toda vez que el turismo y los insumos del comercio y los servicios asociados representan más del cincuenta por ciento de su PIB, su baja fiscalidad es también característica de este microestado europeo (exención de tributación sobre las rentas y los derechos aduaneros). Esta singularidad resulta reforzada por el hecho, no menor, de que en sus Tratados Bilaterales con Italia figura la previsión de una transferencia presupuestaria directa por parte de los Presupuestos de la República Italiana para gastos ordinarios de funcionamiento y servicios de su administración. San Marino se incardina, en lo demás, como Estado soberano en la comunidad internacional y en las organizaciones internacionales y de protección de derechos humanos propias de su entorno europeo, habiendo promovido también sus reformas obligadas para instrumentar la estrategia de reformas requerida por la UE para la investigación de evasión de capitales y del blanqueo de dinero procedente de negocios ilícitos.

\section{BREVE VALORACIÓN DE SUS SINGULARIDADES ANTE LA PERSPECTIVA DE SU ASOCIACIÓN CON LA UE.}

Tras este apretado repaso de los episodios históricos y constitucionales de estos pequeños Estados enclavados en Europa, ha de notarse, sin embargo, que, como se colige, los tres comparten la rareza de su escala diminuta, pero son distintos entre sí. Lo es cada uno de ellos en su propia mismidad, enclavados en la Europa que resurge de sus cenizas tras la Segunda Guerra Mundial ${ }^{32}$, en el marco de las experiencias de integración supranacional en dos círculos concéntricos: Primero, el del Consejo de Europa (Tratado de Londres, 1949), que integra hoy a 47 Estados miembros (EE.MM), con su relevante Convenio Europeo de Derechos Humanos (CEDH, Convenio de Roma de 4 de noviembre de 1959), sus 14 Protocolos, y su órgano de garantía jurisdiccional de derechos (el TEDH, con sede en Estrasburgo); Y segundo, el de la Unión Europea (UE), que descansa hoy en el Tratado de Lisboa y en la Carta de Derechos Fundamentales de la UE (en vigor desde el 1 de diciembre de 2009), cuya garantía jurisdiccional (principios de primacía, eficacia directa, interpretación uniforme, autonomía y efecto útil) asegura

32 Para una aproximación comparativa de amplio espectro tanto de las características definitorias de los microestados como del modo en que el tamaño se refleja en las políticas, véase PlitsCHKe, E.: Microstates in World Affairs: Policy Problems and Options, American Enterprise Institute for Public Research, Washington D.C, 1977. 
el TJUE con sede en Luxemburgo, y de la que, tras el Brexit (2020) forman actualmente parte 27 EE.MM (todos ellos integrados en el Consejo de Europa).

De modo que estos tres microestados, largamente refractarios al escrutinio del Derecho comparado, no son entre sí confundibles, como tampoco sus respectivos patrimonios jurídicos son miscibles ni indistintos. Requiere cada uno de su análisis. Y sus pormenores merecen también una recepción específica para su eventual encaje, con todos los matices que se estimen pertinentes, en el Derecho europeo y el acquis communautaire. Y la merecen además en el concreto contexto de la estrategia lanzada por la Comisión Europea durante el mandato de su Presidente J.C Juncker (2014-2019) para completar un Acuerdo de Asociación entre la UE y Andorra, San Marino y Mónaco. Un Acuerdo que, no obstante haber recibido con su Interim Report el voto favorable del PE - tanto de la Comisión proponente (Comisión AFET) como del Pleno en Estrasburgo-, a día de hoy forma parte de la bandeja de asuntos pendientes (pending files) traspasados desde la anterior Legislatura europea (2014/2019) a la actual Legislatura (2019/2024). En modo que ahora corresponde al mandato de la Comisión Von der Leyen 2019/2024 llevar a término la negociación en curso, con su sometimiento a su definitiva votación (Final Say) por el Pleno del PE (art. 218 TFUE). Pero expongamos ahora los antecedentes de las negociaciones conducentes a la conclusión de este Acuerdo de Asociación europea entre la UE y los tres Estados de que venimos ocupándonos.

\section{El mandato de negociaciones para un acuerdo de asociación entre la UE y los microestados}

Cabe comprimir ahora aquí los jalones más señeros del establecimiento de las bases y posterior puesta en marcha de la negociación en curso. Como primer estadio, en 2014 el Consejo adoptó la Decisión de mandatar a la Comisión Europea el inicio de negociaciones de uno o varios Acuerdos de Asociación con el Principado de Andorra, el Principado de Mónaco y la República de San Marino. La comprensión de esta estrategia de Asociación europea requiere subrayar el papel que el Tratado de Lisboa (TL) reserva al Parlamento Europeo (PE). El art. 218 del TFUE reserva al PE su «Final Say» (voto final y decisivo sobre el conjunto del texto) para la ratificación de todo Tratado, Acuerdo o cualquier otro instrumento de Derecho internacional negociado por la Comisión Europea por mandato del Consejo, condición sine qua non para su entrada en vigor ${ }^{33}$. Por su parte, el art. 8 TUE — cláusulas definitorias del TL_ establece que la UE tendrá en cuenta la situación particular de los países de pequeña dimensión territorial con los que mantiene relaciones de proximidad. Sobre esta base, la Comisión Europea había dictado previamente su Comunicación: «Relaciones de la UE con el Principado

33 Para más detalle, Lopez Aguilar, J.F., El Parlamento Europeo: una experiencia única, op. cit, 2020. 
de Andorra, Principado de Mónaco y la República de San Marino - Opciones para una mayor integración en la UE (COM 2012/0680). Esta Comunicación se hizo acompañar de dos Documentos de trabajo. Por un lado, un Working Document on the Obstacles to Access by Andorra, Monaco and San Marino to the EU Internal Market and Cooperation in other Areas»; por otro, un posterior Informe, de 18 de noviembre de 2013, sobre las Relaciones de los mencionados microestados con el Mercado Interior. Con posterioridad, el Consejo adoptó sus Conclusiones de 11 de diciembre de 2018 sobre un Mercado interior homogéneo y ampliado y sus relaciones con países occidentales no pertenecientes a la UE, categoría esta que, obviamente, incluye a los tres microestados. Así, de conformidad al art. 113 del Reglamento Interior del PE (Rules of Procedure, o $R o P$ ), tras la deliberación, debate y aprobación del Informe de su Comisión de Asuntos Exteriores del PE (AFET) sobre la negociación de un Acuerdo (conjunto) de Asociación de la UE con los tres microestados, el Pleno del PE adoptó su preceptivo Informe de Recomendaciones para la conclusión de la negociación de 11 de febrero de 2019. Su conclusión recae ahora sobre la Comisión Europea en su mandato 2019/2024 (la Comisión VDL). Su votación final, conditio de su entrada en vigor, corresponde al PE elegido en mayo de 2019 para la Legislatura 2019/2024.

\section{Un punto de apoyo: las bases jurídicas y políticas para el reconocimiento de un trozo de historia europea}

Clavados entre sus vecinos, Estados miembros de la UE que cuentan con poblaciones, territorios, organizaciones político-administrativas, Defensa y Fuerzas Armadas incomparablemente mayores, los tres microestados exhiben orgullosamente sus credenciales como Estados soberanos e independientes en el continente europeo, indisputadamente reconocidos en la comunidad internacional de naciones. Cada uno de ellos mantiene fronteras exteriores pacíficamente acordadas, constantes en la historia moderna y contemporánea, consolidadas en cada uno de sus perímetros, con tres EE.MM de la UE con los que les vinculan Acuerdos bilaterales (que incluyen, en los específicos casos de Mónaco y San Marino, compromisos de Defensa por parte de Francia e Italia; respectivamente): Andorra con España y Francia; San Marino con Italia; Mónaco enclavado en Francia, pero muy próximo a la frontera con Italia. No extraña que estos tres microestados hayan ocupado largamente su lugar propio y singular en la historia general de Europa. Ni que hayan mantenido relaciones políticas, económicas, sociales y culturales profundas y de larga data con su vecindad inmediata. Ni puede ignorarse tampoco que estos tres microestados pertenecen además al círculo concéntrico de integración que es el Consejo de Europa (47 EE.MM), cuyo producto más granado es el CEDH de 4 de noviembre de 1950 y sus Protocolos Anexos, y cuya garantía jurisdiccional desempeña el TEDH con sede en Estrasburgo. De modo que la Asociación de la UE 
con estos tres países se fundamenta también en un conjunto común de valores jurídicos y culturales.

\section{Análisis de los contenidos de la resolución del PE sobre el acuerdo de asociación entre la UE y los microestados}

El primer punto concierne a los caracteres de la Resolución del PE derivados del procedimiento parlamentario aplicable. Se trata del procedimiento de Informes de Iniciativa (INI Reports), que concluyen con recomendaciones y mandatos a la Comisión para que adopte la correspondiente iniciativa legislativa (art. 225 $\mathrm{PE})$. Las conclusiones del INI pueden entenderse, pues, como una fórmula parangonable a las que el Derecho comparado del parlamentarismo de los EE.MM conoce como «Mociones» dirigidas al Gobierno (consecuencia de interpelación) o como PNL, en el Derecho parlamentario español. En este caso el Informe INI equivale grosso modo a la PNL. Conforme a esta técnica de Informes de Iniciativa (INI Reports), el PE adoptó en su Pleno de Estrasburgo de febrero de 2019 su Proyecto de Recomendación — dirigido al Consejo, a la Comisión y a la Vicepresidenta/Alta Representante de la Unión para Asuntos Exteriores y Política de Seguridad - sobre el Acuerdo de Asociación entre la UE y los microestados. Se trata del Informe de Iniciativa 2018/2246(INI), del que tuve honor de ser Ponente del PE (Comisión AFET).

El PE arranca esta Resolución, sobre la base jurídica que presta la Decisión del Consejo (UE) de 22 de diciembre de 2014, reivindicando la potestad decisiva sobre el resultado final de la negociación que proporciona al PE el artículo 218 del TFUE. Con tan importante función, sólo el PE autoriza, mediante su voto de conformidad final (consent procedure, art. 218 TFUE), la ratificación final y definitiva (condición de su entrada en vigor) de cualesquiera Tratados y Acuerdos internacionales negociados, completados y suscritos por la UE dentro de sus competencias (que incluyen las de la ordenación del comercio global por medio de Acuerdos comerciales) en su calidad de sujeto de Derecho internacional con personalidad jurídica única (art. 47 TUE). El PE marca aquí una diferencia con el patrón comparado de los Parlamentos nacionales, en los que es raro encontrar un caso de empoderamiento que otorgue a su Cámara legislativa el poder de decidir sobre la entrada en vigor de cualesquiera Acuerdos, Convenios o Tratados de Derecho internacional general, o desautorizar por entero la negociación conducida por el órgano que ejerza la dirección política de la acción exterior (residenciada normalmente en el Ejecutivo o Gobierno, Departamento de Estado o Ministerio de AAEE) ${ }^{3435}$.

34 Un análisis reciente, en Costa, O., The European Parliament in Times of EU Crisis: Dynamics E Transformations, Palgrave Mac Millan, London, 2019.

35 Por lo demás, es reseñable que esta potestad ha sido ya puesta a prueba con el voto negativo, y consiguiente desactivación de la expectativa de Acuerdo que había sido sometida a la decisión del PE en unas 
Entrando en materia, las Recomendaciones del PE empiezan por apreciar las singularidades históricas de las tres entidades políticas implicadas en cuanto Estados soberanos. En el curso de la negociación, los tres microestados exhiben la narrativa articulada de sus prolongadas historias de soberanía e independencia en el continente europeo. Tal y como se recoge en la literatura de la Resolución, los tres y cada uno de ellos han ocupado «desde siempre un lugar central en la historia europea». Y han mantenido relaciones políticas, económicas, sociales y culturales profundas de larga data con los EE.MM situados en su vecindad inmediata y con la UE en su conjunto. Cualquier futura asociación de la UE con estos países deberá fundamentarse, pues, en un conjunto común de valores jurídicos culturales: valores civilizatorios que integran el así llamado «modelo social europeo». En esta toma de razón, los tres han explicitado repetidamente su «vocación política, económica y cultural netamente europea». Y arrancan su negociación desde el expreso deseo — ratificado como tal en los respectivos órganos de representación democráticas de sus ciudadanías- de «estrechar» sus relaciones políticas, económicas y culturales con la UE. De modo que, en interés de Andorra, Mónaco y San Marino, por una parte, y de la UE, por la otra, se aprecia como relevante el objetivo estratégico de la negociación: responder positivamente a la vocación europea de los tres microestados mediante una aproximación de posiciones flexible y oportuna. Pero se apuesta también -es el criterio del PE en su Recomendación- por facilitar una conclusión preferiblemente rápida de las negociaciones del perseguido nuevo Acuerdo de Asociación que habrá de constituir el nuevo marco general para las relaciones entre la UE y estos tres microestados. Desde el reconocimiento que el objetivo expreso en ningún caso contempla ni apunta a su adhesión formal —ninguno de ellos pretende la adhesión ni aspira a ser Estado miembro de la UE_-, sino a la optimización de las potenciales sinergias de una aproximación mutuamente rentable para una parte y las otras.

El objetivo de la negociación redunda, particularmente, en el especial interés de aquellos Estados miembros que tradicionalmente han mantenido estrechos vínculos históricos, políticos y económicos. Para su concreción e intensificación, que resulta esencial tener en cuenta en toda la negociación el acervo de Tratados y convenios por los que se articulan las relaciones bilaterales especiales de esos tres Estados miembros con los tres microestados, siquiera por consideraciones de seguridad jurídica. Interesa especialmente la incorporación de Andorra a la organización jurídica de las Conferencias bianuales de la Comunidad Iberoamericana. En esta dimensión exterior, es útil reconocer que, tradicionalmente, los microestados concernidos han venido respaldando las líneas políticas acordadas por la UE

cuantas ocasiones de gran calado político (Acuerdo Swift de Intercambio de Información con los EEUU en materia de Transacciones Financieras y Rastreo de Financiación del Terrorismo, en 2010; Tratado contra el Counterfeiting (Falsificaciones Industriales), 2015; Acuerdo Textil UE/Uzbekistán, en 2016, entre otros casos. Cfr, sobre estos aspectos relativos a la especificidad de la denominada Diplomacia Parlamentaria del PE, STAvridis, S., Irrera, D., The European Parliament and its International Relations, Routledge, London, 2016. 
en su Consejo de Asuntos Generales, bajo la dirección de la diplomacia europea que corresponde al High Rep, en las organizaciones internacionales a las que pertenecen, y por las que se articula actualmente la globalización. Para empezar, en las Resoluciones de la Asamblea General de las NNUU y en sus Conferencias ad hoc sobre objetos especializados (Global Pact on Migrations $\mathcal{E}$ Asylum, entre otras). Los tres son, cada uno por derecho propio, socios de peso para los EE.MM de su frontera inmediata, con especial efecto económico en las regiones colindantes (Pirineos orientales, Cataluña, Emilia Romagna, Le Marche, Liguria...).

Nada de eso excluye una razonable cautela a la hora de entablar la fase definitiva y final de las negociaciones del Acuerdo de Asociación con los tres Estados referidos. Es la que se refiere a la importancia tomar plenamente en consideración, a tenor de la Declaración 3 relativa al artículo 8 del TUE, «las especificidades de Andorra, Mónaco y San Marino como países de muy pequeño tamaño y, consiguientemente, capacidad material proporcionalmente reducida para asimilar las reglas del mercado interior» que constituyen el umbral de acceso o de adhesión para las economías de mayor escala. Por identidad de razón, será crucial tener en cuenta las implicaciones prácticas de la pequeña dimensión territorial y de su muy reducido número de habitantes. Y todo lo que ello implicará para reglar unos términos de acceso a bienes, mercancías y servicios, que resulten adecuados y, en última instancia, aceptables y atractivos para la ciudadanía de los tres microestados, toda vez que serán sus órganos de representación (sus respectivos Parlamentos) $-\mathrm{y}$, en el caso de Andorra, su pueblo, en un referéndum de ratificación comprometido formalmente en el inicio de las negociaciones- quienes habrán de dictar la última palabra respecto a su ratificación y su entrada (o no) en vigor. En rigor, cabe añadir que esa ponderación de sus respectivas condiciones objetivas y materiales para la inclusión y acceso de cada una de esas entidades soberanas europeas al mercado interior resultan en sí esenciales para la continuidad de la cultura, las tradiciones y los valores acendrados en sus historias propias. Es más, cabe anticipar que sin unos mecanismos de inclusión y de acceso específicos a las reglas del mercado interior de la UE, buena parte de la ciudadanía en cada uno de esos tres microestados podría verse compelida a grandes dificultades para poder continuar en su país de origen con expectativas fiables de bienestar o acomodo de su generación o de las venideras. Parece sensato, pues, respetar mediante las disposiciones que se estimen adecuadas en el Acuerdo de Asociación, los límites de su tejido político, socioeconómico, cultural e identitario, vulnerable en tanto que reducido, para, en lo posible, adaptarlo a las condiciones del acquis de la UE. Los tres plantean para ello una malla selectiva de Acuerdos bilaterales con sus países vecinos (España, Francia e Italia) en que se abordan cuestiones comprendidas como de interés mutuo. Acuerdos que tienen en cuenta sus particularidades y sensibilidades, conscientes de la necesidad de preservar la viabilidad y sostenibilidad de sus microestados, particularidades, por lo demás, expresamente reconocidas también en sus respectivas modalidades de acceso al Consejo de Europa y al TEDH, así como por las Resoluciones de la Asamblea 
Parlamentaria del Consejo de Europa. Ampliando el foco, es un hecho que tanto la crisis del Brexit (2016/2019) como la del Covid19 (2020) han endurecido el clima de la negociación en curso, estrechando aún más las condiciones para completarla con éxito en los calendarios fijados en el diseño de su "perímetro y tiempo». La emergencia sanitaria ha puesto de manifiesto la importancia decisiva de la cooperación transfronteriza e interregional. Por eso el proyectado Acuerdo contiene capítulos precisos sobre las oportunidades de cooperación con la EU especialmente aplicables a sus EE.MM vecinos y regiones fronterizas, así como a la participación de los tres microestados en los Programas europeos de su mayor interés, concretando en cada caso los mecanismos financieros.

Ahora bien, es también cierto que hay un aspecto concreto de sus antecedentes jurídico-institucionales que plantea dificultades que han de ser subestimadas ante un rasgo compartido por estos tres microestados: su reputación negativa, su problemático historial de "paraísos fiscales» con capacidad de imantar capitales en fuga de los países terceros en que se generaron, ya fueran rentas o ganancias, ya fueran lícitos o ilícitos dichos negocios en su origen ${ }^{36}$. En lo que respecta al problema — ciertamente discutido- de su planta financiera y de su disposición a cooperar con las jurisdicciones penales y administrativas competentes contra la ocultación de capitales y el blanqueo, cabe reseñar, sin embargo, recientes y notables progresos que no pueden tampoco ser ignorados sin más. A lo largo de la primera década del siglo (bajo la influencia de los organismos especializados del Consejo de Europa y de la OCDE, en el contexto de la apertura progresiva de sus economías) Andorra, Mónaco y San Marino, cada uno por su cuenta, han emprendido significativas estrategias de reforma de las arquitecturas de sus sistemas financieros. Con actuaciones y medidas que han sido, en el curso del tiempo, avaladas por la OCDE y sus Grupos especializados contra la corrupción, expresamente orientadas a la búsqueda de una progresiva convergencia normativa con la UE y con particular detalle en lo que se refiere a la regulación del sector bancario y financiero. Sus estrategias han devengado efectos prácticos. Así, como consecuencia, en su reunión del 4 de diciembre de 2018, el Consejo de la UE decidió retirar al Principado de Andorra y a la República de San Marino del Anexo II de las Conclusiones del Consejo de 5 de diciembre de 2017 (la llamada «lista gris», a la que previamente habían transitado, superando su anterior consideración como Estados calificados como «jurisdicciones no cooperativas»). Lo que equivale a confirmar que estos dos microestados han venido a cumplir todos los compromisos pendientes relativos a la transparencia, la equidad fiscal y las medidas contra la erosión de la base imponible y el traslado de beneficios ${ }^{37}$. Por su parte, el Principado de Mónaco nunca llegó a figurar en el mencionado Anexo II. El 5 de

36 Vid. sobre estos detalles, InAm, P., Exchange Rate of Microstates, IMF; Washington D.C, 2010.

37 Para una elaboración de este punto, enfocado en perspectiva, cfr. Hampton, M., Microstates and OffShore Finance: The Politics of Vulnerability, Univ. of Plymouth, SouthSea, Hampshire, 1999. 
diciembre de 2017, el Consejo constató el «pleno respeto» de dichos compromisos por parte de este microestado. El Foro Global sobre Transparencia e Intercambio de Información con Fines Fiscales de la OCDE declaró, en sus reuniones de abril y julio de 2018, que los tres países habían obtenido la calificación de «conforme» en relación con la norma internacional relativa al intercambio de información previa solicitud y/o requerimiento de autoridades competentes para su investigación ${ }^{38}$.

Teniendo en cuenta, finalmente, que el proyectado Acuerdo de Asociación europea de los tres microestados requerirá la aprobación del PE para su entrada en vigor (art. 218 TFUE), en su Resolución de febrero de 2019 la Eurocámara incorpora un abultado conjunto de Recomendaciones específica, dirigidas al Consejo, a la Comisión y al Vicepresidente de la Comisión/Alto Representante (High Rep) de la UE para Asuntos Exteriores y Política de Defensa y Seguridad común. Incluye en ellas el fomento de los intercambios periódicos de puntos de vista (exchange of views) con las Delegaciones parlamentarias nacionales de los tres microestados; empezando por el curso de las negociaciones. Tanto el PE como las Delegaciones parlamentarias nacionales de los tres microestados deberían comprometerse a mantener el mismo tipo de intercambios regulares acerca de aquellas cuestiones y materias comprendidas en el ámbito de competencias legislativas del PE (reforzadas como nunca antes desde la entrada en vigor del TL y la CDFUE) que pudieran afectar de una manera directa a su economía, demografía, parámetros de bienestar o a su relación con la UE o a la integridad y eficacia del propio Acuerdo de Asociación.

\section{REFLEXIONES CONCLUSIVAS.}

Visitándonos directamente desde el Tratado de Westfalia (1648), algunos de los más pequeños e, irónicamente, más antiguos Estados de la comunidad internacional de las naciones tienen su asiento en Europa, continente en cuyos valores y parámetros culturales y civilizatorios se incardinan, y en cuyo primer círculo de integración supranacional (Consejo de Europa, Asamblea Parlamentaria del Consejo de Europa y TEDH) han adquirido también su representación ${ }^{39}$.

Tiene sentido que completen su modalidad específica de asociación al círculo de integración supranacional más avanzado (la UE), individualizada en lo que sea menester. En un repaso estas especialidades, resulta imposible no reparar en el impacto de su escala. Tanto el pluralismo político de su representación —sus respectivos Consejos (Parlamentos locales)— como también, sobre todo, sus pautas

38 Véase el documentado análisis de Inam, P., Kouwenaar, A., Rapid Current Account Adjustment: Are Microstates different?, IMF, Wahington D.C, 2008.

39 Para una ilustración de este proceso, cfr. Duursma, J., Fragmentation and the International Relations of Microstates: Self-Determination and Statehood, Cambridge Univ. Press, Cambridge, 1996. 
de cambio social y político sólo pueden comprenderse correctamente a partir de esta conciencia de su escala. ¿Sería comprensible de otro modo que haya tomado tanto tiempo el tránsito hacia el sufragio universal con extensión del derecho de voto a las mujeres? ¿O la dilación del tiempo en que sus cuerpos legislativos cristalizan en algo parecido a una codificación política o Constitución escrita?

Sólo su progresiva apertura al exterior y la penetración de sus influencias, y su interacción con ellas - comenzando por su entorno inmediato indefectiblemente europeo- explican la pauta política de su asimilación de estándares y de aproximación a los círculos concéntricos de la integración europea. Primero, al Consejo de Europa (CEDH, jurisprudencia del TEDH); luego, al acquis соттиnautaire (TL, CDFUE, jurisprudencia del TJUE). Por ello, seguramente, el análisis comparativo refleja puntos de interés, pero también sus limitaciones. Por supuesto es instructivo conocer ordenamientos extranjeros que son genuinas rarezas, escasamente advertidos, a los que casi nunca hemos prestado atención. Pero es también evidente que sus categorías y pautas de transformación aparecen determinadas por el acotamiento extremo del microcosmos diminuto sobre el que se proyectan y desde el que comparecen ante los demás: la ciencia del Derecho constitucional comparado en Europa, y en el mundo. De modo que, si bien es cierto que hay patrones de Derecho europeo que ilustran la utilidad del examen de las situaciones jurídicas e institucionales de los microestados europeos, también lo es que su correcto manejo por parte de las Instituciones de la UE debe partir de una sensata ponderación de los límites impuestos por su propia escala. En otras palabras, si es cierto que el acervo comunitario se basa en las cuatro libertades vertebrales de la construcción de su mercado interior (libre circulación de bienes y mercancías, libre circulación de servicios y establecimientos, libre circulación de capitales, libre circulación de personas), también lo es que la Asociación estratégica apuntada en las negociaciones deberá dar cuenta de los límites a la libre circulación y elección de residencia que impone la consideración (y respeto) a esa inexorable escala.

La alternativa supondría asumir lisa y llanamente el riesgo del fracaso de esas negociaciones, nada más y nada menos, por una razón que no enaltece ni a la UE ni a su estrategia de influencia y su denominado soft power en la globalización. Empezando por su propio marco de interacción inmediata: tres pequeños Estados fronterizos con otros tantos EE.MM (España, Francia e Italia). La probabilidad de que, por rigidez o por incomprensión de estos límites, la conclusión del Acuerdo de Asociación resultante pueda ser validada por el voto favorable del Pleno del PE (art. 218 TFUE) y, sin embargo, rechazada en las votaciones definitivas de ratificación de las instituciones representativas de los microestados examinados, o rechazada, aun peor, en referéndum consultivo convocado a ese propósito (como es el caso del Principado de Andorra, cuyo Consejo de Gobierno se comprometió expresamente a someterlo a ese refrendo en el momento de recabar respaldo parlamentario para el inicio formal de las negociaciones), debe ser calibrada como un riesgo cierto, y, por serlo, difícilmente asumible. 
Por un lado, hace tiempo que la situación por la que atraviesa la UE ha de ser calificada sin ambages como la de la más grave crisis existencial que recuerde desde que se puso en marcha. Lo que sin lugar a duda afecta a su reputación. Es la desembocadura de una sofocante serie de episodios de crisis sin precedentes: Gran Recesión a partir de 2009, con la «crisis del euro» y de la «deuda soberana»; la mal llamada «crisis de los refugiados» y el desmoronamiento de la confianza mutua (arts.81 y 82 TFUE) y de la voluntad de Europa; el Brexit y la emergencia de plataformas políticas eurófobas, sea en su versión populista o sea en su versión ultranacionalista o de extrema derecha reaccionaria; y, ya en 2020, la crisis del Covid19 con su emergencia sanitaria y su imponente desafío a la recuperación tras el obligado parón económico y el estrago social debido a la suspensión de la libre circulación y del espacio Schengen.

Quiere sugerirse con ello que la UE debe ser consciente de que debe reapuntalar su propia confianza en sí misma para volver a mejorar su reputación exterior; para volver a ser, en otras palabras, un polo de atracción para Estados terceros, y un factor de emulación (leading by example) para otros actores regionales con vocación global (como lo fue durante décadas para la integración regional en Latinoamérica, África o el sudeste asiático). De modo que, para imantar y seducir a las ciudadanías de los pequeños Estados europeos de su frontera interior, al menos debería ser capaz de dar una imagen de sí misma como horizonte inescapable -y desde luego preferente - para la articulación de las distintas fórmulas de Asociación que se exploran en la negociación en curso.

En este punto, es evidente que la erosión acumulada a la confianza mutua entre los EE.MM y el desfallecimiento de la voluntad de Europa ha afectado a la estrategia para su futura ampliación: «enlargement fatigue» es la expresión que da cuenta de ese cansancio que pospone de forma cada vez más ruda y desacomplejada la «fatiga de nuevas ampliaciones ${ }^{40}$. Se expresa con esta imagen, tan propia de la jerga europea, que nadie vislumbra ventajas en ensanchar el perímetro de la UE incorporando microestados de escalas inasimilables para las actuales reglas de participación en las Instituciones de la arquitectura europea (asientos en el PE, cartera en la Comisión Europea, voz y voto en el Consejo, magistrado(s) en el TJUE, vocal en el Tribunal de Cuentas...). Ni lo desean los Gobiernos ni las Asambleas parlamentarias de estos tres microestados, ni está tampoco en la agenda de la negociación. Nadie apunta, por lo tanto, a que el Principado de Andorra, el Principado de Mónaco y la República de San Marino se adhieran al club ni aspiren a la membresía en la UE; tampoco, siquiera, a estimular esa aspiración en sus órganos de gobierno y representación y en sus ciudadanías. El objetivo es muy otro: una razonable y acotada Asociación operativa que devengue

40 Sobre el desfallecimiento de la voluntad de Europa, minada por el crecimiento en número y entidad de las formaciones políticas de extrema derecha, populistas, nacionalistas reaccionarias y/o rabiosamente eurófobas, me remito a López Aguilar, J.F., Europa: ¿Suicidio o Rescate? Tirant-Lo Blanch, Madrid, 2013. 
mejoras y beneficios tangibles en una y otra dirección respecto del hasta ahora (y actual) status quo.

La conclusión en este punto es meridiana: interesa a la UE mostrar altura de miras, flexibilidad, contención, y cierta visión estratégica para apuntalar el acuerdo con los tres microestados mirando a la persuasión y a la capacidad de atracción que ese esfuerzo requiere en los microuniversos, social y políticamente acotados, de cada uno de ellos. Por eso no huelga el examen comparado en perspectiva europea. Tiene, con toda la modestia que imponen sus limitaciones, utilidad y propósito. Y es por ello desde ese encuadre que hemos repasado aquí sus itinerarios históricos y constitucionales, cada uno de ellos con especificidades carentes de parangón en el Derecho comparado de los Estados europeos, aun cuando revestidos de los rasgos distintivos de una democracia representativa, regida bajo el imperio de la ley y con separación de poderes, pluralismo político, elecciones libres y periódicas y garantía de derechos por un Poder Judicial independiente, pluralismo político y protección de minorías (valores que el art. 2 TUE consagra como «valores comunes» del constitucionalismo de los Estados miembros), con todas las limitaciones debidas, explicablemente, a su escala y a los propios confines de sus posibilidades materiales. Acaba así de condensarse la perspectiva constitucional europea como marco de comparación para el mejor conocimiento y valoración de las peculiaridades de los microestados enclavados en territorio europeo. Siendo de aplicación a las comunidades académicas de todos los Estados miembros de la UE, revisten singular interés en las comunidades científicas y académicas de los que tienen fronteras con alguno de esos microestados. El Reino de España, entre ellos. Siquiera sea porque la presencia de ciudadanos/as españoles en las administraciones andorranas, en la cobertura de posiciones de relieve en su estructura judicial (Tribunal Constitucional, incluyendo su presidencia) aconsejan un mayor y mejor conocimiento de este ordenamiento vecino.

Sorprende, por eso mismo, el escaso eco hasta ahora entre los comparatistas españoles de la importante Constitución andorrana de 1993. Porque esta no sólo efectuó en su momento un salto adelante cualitativo (carácter y fuerza normativa de una Constitución escrita revestida de fuerza normativa, derechos y libertades garantizados, con sus partes dogmática y orgánica exhibiendo claras influencias del Derecho constitucional español y de sus desarrollos doctrinal y jurisprudencial), sino que ha servido de base para una resuelta inserción del Principado de Andorra en una suerte de nueva normalidad en ámbitos que tradicionalmente venían siendo problemáticos: la cooperación financiera con la jurisdicción penal de los estados miembros de la UE y la homologación con los estándares de transparencia requeridos por la OCDE, por el Consejo de Europa ( «Grupo GRECO contra la corrupción») y por la propia UE.

El específico trayecto de Andorra resulta aleccionador, Estado fronterizo cuya resiliencia en resultaría inexplicable sin su engarce en los jalones de la historia de España. Incluidos los que explican que el obispo titular de la sede 
episcopal de la Seu d'Urgell sea, desde hace siglos, copríncipe junto al fijado por las distintas figuras que se han sucedido en la jefatura de Estado de Francia (desde los Reyes capetos al actual Presidente de la República, pasando por los Reyes borbones, I República, Consulado e Imperio de Napoleón I, Restauración borbónica y Monarquía orleanista, II República, II Imperio con Napoleón III, III República, IV República, hasta llegar a los sucesivos Presidentes de la actual V República bajo la Constitución francesa de 1958).

Y la última conclusión es asimismo clara. Con la debida atención a los requerimientos de la categoría de la «identidad nacional» de los EE.MM de la UE (art. 4 TUE), en conjugación con los valores del art. 2 TUE y con el resto de las bases del TL (arts.3 a 6 TUE) y de la CDFUE, estudiar los microestados europeos, tanto para conocerlos como para comprender la complejidad y diversidad de Europa («United in Diversity» es el lema de la UE), es una contribución —-modesta, pero no despreciable - al desarrollo y a la amplitud del espectro del Derecho comparado en España y en la UE

TITLE: European microstates in view of their upcoming EU Association Agreement

ABSTRACT: This essay aims to focus on the specific features — both historical and constitutional - of three European microstates: the Principality of Andorra, the Principality of Monaco and the Republic of San Marino. It tackles this subject under a Comparative Legal approach, insofar as they fit into the standards of European democratic and social Constitutionalism, in view of their upcoming EU Association Agreement (on which the European Parliament adopted its Recommendations, February 2019). Its joint undertaking lies on four considerations. Firstly, they are all European States; and yet, hardly ever seen as such by the European Scholarly writings, not even by their closest neighbouring partners. Secondly, it is interesting to highlight their common features (European legal culture, small dimension, legal and political heritage that have proved resilient to upheavals all around), while singling out their uniqueness, leading to conclude that each of them is one of a kind their own way. Thirdly, all three microstates are included in a currently ongoing negotiating process, aimed to tighten their links with the EU acquis by means of a future EU Association Agreement (which is not the case of Liechtenstein, nor the Vatican City). As to this procedure, the European Parliament shall have its final say on the outcome and its entry into force (art.218 TFEU). And fourth: getting to know better these three microstates can also compensate a persisting lacuna, which is meaningful, at the light of intense crossborder links, with Spain (case of Andorra), France and Italy (case of Monaco), and Italy (case of its enclaved Republic of San Marino).

RESUMEN: Este artículo acomete una aproximación a las especificidades histórico-constitucionales de tres microestados europeos: Principado de Andorra, Principado de Mónaco y República de San Marino. La aborda desde el Derecho comparado y desde su común encuadramiento en las categorías del constitucionalismo europeo democrático y social, pero también a la vista de su futuro Acuerdo de Asociación con la UE, sobre el que el Parlamento Europeo (PE) adoptó una Resolución con sus Recomendaciones en febrero de 2019. Su tratamiento conjunto responde a cuatro órdenes de consideraciones. Primero, siendo Estados europeos, raramente reciben atención en la doctrina europea, ni siquiera en los Estados miembros de la UE de su vecindad inmediata. Segunda, reviste interés delinear sus rasgos compartidos (cultura jurídica europea, reducida dimensión, estructuras jurídico-políticas beredadas de la historia con llamativa resiliencia frente a los sucesivos ciclos de cambio que se ban producido alrededor), al tiempo que espigar sus singularidades, para concluir que cada uno de ellos es en cierto modo único en su género. Tercera, los tres microestados elegidos para este examen conjunto 
se encuentran actualmente incursos en un procedimiento de acercamiento a la UE mediante la negociación de un futuro Acuerdo de Asociación con la UE (lo que les diferencia de los casos de Liechtenstein y Ciudad del Vaticano), sobre cuyo resultado y eventual entrada en vigor el PE ostenta la última palabra (art. 218 TFUE). Y una cuarta razón: mejorar el conocimiento de estos tres microestados ayuda también a compensar una persistente laguna o déficit de tratamiento. Un descubierto llamativo teniendo en cuenta que los tres mantienen intensos lazos transfronterizos con otros tantos EE.MM de la UE, incluyendo España y Francia en su frontera con Andorra, Italia y Francia con Mónaco, e Italia con su enclave interno en la República de San Marino.

KeY wORDS: European microstates, the Principality of Andorra, the Principality of Monaco, the Republic of San Marino.

Palabras clave: Microestados europeos, Principado de Andorra, Principado de Mónica, Republica de San Marino.

FECHA DE RECEPCIÓN: 09.05.2020

FECHA DE ACEPTACIÓN: 09.09.2020 